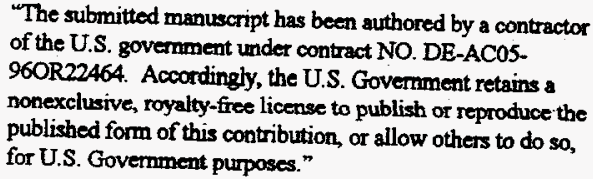

\title{
CERAMIC FILTERS
}

B. L. Holmes* and M. A. Janney, Oak Ridge National Laboratory, Oak Ridge, TN $37831-6087$

\begin{abstract}
Filters were formed from ceramic fibers, organic fibers, and a ceramic bond phase using a papermaking technique. The distribution of particulate ceramic bond phase was determined using a model silicon carbide system. As the ceramic fiber increased in length and diameter the distance between particles decreased. The calculated number of particles per area showed good agreement with the observed value. After firing, the papers were characterized using a biaxial load test. The strength of papers was proportional to the amount of bond phase included in the paper. All samples exhibited strain-tolerant behavior.
\end{abstract}

Keywords: ceramic fiber; filter; papermaking

\section{INTRODUCTION}

Fibrous filters have been used for centuries to protect individuals from dust, pathogens ceramic filters were developed for filtration of hot exhaust gases from diesel engines[2-4]. Tubular, or candle, filters have been made to remove particles from gases in pressurized fluidized-bed combustion and gasification-combined-cycle power plants [5]. Very efficient filtration is necessary in power plants to protect the turbine blades. The limited lifespan of ceramic candle filters has been a major obstacle in their development.

The present work is focused on forming fibrous ceramic filters using a papermaking technique. These filters are highly porous and therefore very lightweight. The papermaking process consists of filtering a slurry of ceramic fibers through a steel screen to form paper. Papermaking and the selection of materials will be discussed, as well as preliminary results describing the geometry of papers and relative strengths.

\section{EXPERIMENTAL}

Four classes of materials were used in making ceramic filters. These were the

Research sponsored by the U.S. Department of Energy, Office of Fossil Energy, Advanced Research and Technology Development Materials Program, [DOE/FE AA 151010 , Work Breakdown Structure Element oRNL-N(A)] under contract DE-AC05-840R21400 with Lockheed Martin Energy Systems, Inc. 
ceramic fiber, an organic binder fiber to hold the paper together and provide strength before firing, a bulking fiber to maintain an open, porous structure, and the ceramic bond phase. The ceramic fibers evaluated were Saffil ${ }^{\otimes}$, Nextel 312 ${ }^{\circ}$, fused quartz fibers (QPC $300^{\circledR}$ and QPC 125®), fiberglass, and two aluminosilicate fibers with alumina to silica ratios of $60 \%: 40 \%$ and $87 \%: 13 \%$. The composition, diameter, and use temperature of the ceramic fibers are summarized in Table I. The QPC quartz fibers were heated to remove sizing prior to paper forming. All fibers were used in chopped form.

Table I. Summary of Ceramic Fibers

\begin{tabular}{|c|c|c|c|c|}
\hline Fiber & $\begin{array}{c}\text { Composi- } \\
\text { tion }\end{array}$ & Diameter & $\begin{array}{c}\text { Continuous } \\
\text { Use Temp } \\
\left.\text { ( }{ }^{\circ} \mathrm{C}\right)\end{array}$ & $\underset{\text { turer }}{\text { Manufac- }}$ \\
\hline Saffil & $\mathrm{Al}_{2} \mathrm{O}_{3}$ & $\begin{array}{l}3 \text { micron } \\
\text { diam. }\end{array}$ & 1600 & ICI \\
\hline Nextel 312@ & $\begin{array}{l}62 \% \mathrm{Al}_{2} \mathrm{O}_{3}: \\
24 \% \mathrm{SiO}_{2}: \\
14 \% \mathrm{~B}_{2} \mathrm{O} 3\end{array}$ & $\begin{array}{c}10-12 \\
\text { micron diam. }\end{array}$ & 1200 & $3 \mathrm{M}$ \\
\hline QPC $300^{\circ}$ & $\mathrm{SiO}_{2}$ & $\begin{array}{c}9 \text { micron } \\
\text { diam. }(3 \mathrm{~mm} \\
\text { long) }\end{array}$ & 1000 & $\begin{array}{l}\text { Quartz } \\
\text { Products } \\
\text { Company }\end{array}$ \\
\hline QPC 125 & $\mathrm{SiO}_{2}$ & $\begin{array}{l}14 \text { micron } \\
\text { diam. (13 mm } \\
\text { long) }\end{array}$ & 1000 & $\begin{array}{l}\text { Quartz } \\
\text { Products } \\
\text { Company }\end{array}$ \\
\hline $\mathrm{Al}_{2} \mathrm{O}_{3}: \mathrm{SiO}_{2}$ & $\begin{array}{c}60 \% \mathrm{Al}_{2} \mathrm{O}_{3} \\
40 \% \mathrm{SiO}_{2}\end{array}$ & $\begin{array}{l}20 \text { micron } \\
\text { diam. }\end{array}$ & 1300 & Zircar \\
\hline $\mathrm{Al}_{2} \mathrm{O}_{3}: \mathrm{SiO}_{2}$ & $\begin{array}{c}87 \% \mathrm{Al}_{2} \mathrm{O}_{3}: \\
13 \% \mathrm{SiO}_{2}\end{array}$ & $\begin{array}{l}8 \text { micron } \\
\text { diam. }\end{array}$ & 1600 & Zircar \\
\hline Fiberglass & $\mathrm{SiO}_{2}$ & $\begin{array}{c}33 \text { micron } \\
\text { diam. }\end{array}$ & 400 & Zircar \\
\hline
\end{tabular}

Polyethylenet, polyesters, polypropylene $\neq$, cellulose acetate ${ }^{\circ}$, cellulose\#, and fibrillated acrylict were tested as binder fibers. Cellulose* and Crestbrook pine ${ }^{+}$ were examined as bulking fiber. Colloidal silica ${ }^{\vartheta}$ and four particulate alkali glasses¥ were used for ceramic bond phases Table II summarizes selected properties of the glasses. The sintering temperature of the colloidal silica was experimentally determined to be $1200^{\circ} \mathrm{C}$.

The ceramic filters were formed using a papermaking technique. It was determined that 9 grams of fibers were sufficient to form a paper approximately $20 \mathrm{~cm} \times 20 \mathrm{~cm}$ 
$x 0.1 \mathrm{~cm}$. The total fiber weight was comprised of $75 \%$ ceramic fiber, $15 \%$ binder fiber, and $10 \%$ bulking fiber. The fibers were mixed in a blender in one liter of water. This slurry was poured into a Williams Standard Handsheet Mold** (Figure 1) and further diluted with water to a volume of 5 liters. Upon draining the water from the handsheet mold, the fibers formed a paper on a stainless steel screen. This

Table II. Glass Bond Phases

\begin{tabular}{|c|c|c|c|c|}
\hline Glass & $\begin{array}{c}\text { Composi- } \\
\text { tion }\end{array}$ & Diameter & $\begin{array}{c}\text { Softening } \\
\text { Temp. }\left({ }^{\circ} \mathrm{C}\right)\end{array}$ & $\begin{array}{c}\text { Sintering Temp. } \\
\left({ }^{\circ} \mathrm{C}\right)\end{array}$ \\
\hline 7052 & $\begin{array}{c}\text { Alkali } \\
\text { Barium } \\
\text { Borosilicate }\end{array}$ & 9.4 micron & 712 & 770 \\
\hline 7056 & $\begin{array}{c}\text { Alkali } \\
\text { Borosilicate }\end{array}$ & 7.6 micron & 718 & 770 \\
\hline 9070 & $\begin{array}{c}\text { Lithia Potash } \\
\text { Borosilicate }\end{array}$ & 17.0 micron & Not Available & 770 \\
\hline & $\begin{array}{c}\text { Alkali } \\
\text { Barium }\end{array}$ & 10.7 micron & 656 & 670 \\
\hline
\end{tabular}

paper could be easily removed from the screen and handled after drying. Ceramic bond phase was incorporated into the paper either by direct addition to the slurry or by dip coating the dried paper in a suspension of bond phase in water.

Comparison of papers formed with the various ceramic fibers and binder fibers was accomplished by determining the average relative strength of papers in tensile tests. Strips of paper $2.5 \mathrm{~cm} \times 0.6 \mathrm{~cm}$ ( 1 inch $\times 0.25 \mathrm{inch}$ ) were loaded axially along the length of the sample to determine the breaking strength of the paper. Results from this test were used to select model systems for further study. Once ceramic fibers and binder fibers were chosen, the ceramic bond phases were compared using a biaxial loading test. Discs $5.8 \mathrm{~cm}(2.3 \mathrm{inch})$ in diameter were cut from fired papers. These discs were place, on a supporting ring of the same diameter, a load was applied in the center of the disc at $7.9 \times 10^{-3} \mathrm{~cm} /$ minute $(0.02 \mathrm{inch} / \mathrm{minute})$, and the breaking load and displacement were recorded. In this way, the different ceramic bond phases could be compared, and the amount of bond phase necessary to obtain acceptable strength could be evaluated.

\section{RESULTS AND DISCUSSION}

\section{Fiber Evaluation}

The relative strength of papers made with the different binder fibers was measured for papers which included Saffil ${ }^{\circledR}$ as the ceramic fiber and cellulose as the bulking fiber. The results are shown in Figure 2. Papers formed with the acrylic fiber were significantly stronger in tension than papers made with the other binder fibers. The 
acrylic fiber is highly branched, or fibrillated, with large numbers of long fibrils. These fibrils are very efficient at mechanically bonding particles or other fibers. The acrylic was the only one of the binder fibers tested which was fibrillated. Its high degree of fibrillation makes this fiber an cxcellent binder fiber for paper.

A similar test was conducted to select appropriate ceramic fibers. The results obtained from as formed, unfired papers made with cellulose acetate binder fiber and cellulose bulking fiber are provided in Figure 3. The goal of this test was to make a filter similar to Whatman analytical filters, and therefore strength alone was not a sufficient criterion to determine which ceramic fibers to study. Qualitative criteria such as brittleness, ease of tearing, the ability to be folded and hold a pleat, and ease of handling were noted and are summarized in Table III. Fiberglass filters proved to be the strongest samples, however papers containing this fiber were very brittle and difficult to handle. The two aluminosilicates performed well in the tensile test, yet resulted in very thin papers which tore easily when removed from the stainless steel screen. Papers made from the Saffilo, Nextel 312 ${ }^{\circledR}$, and quartz (QPC ${ }^{8}$ ) fibers were similar in relative strength. Papers made with Nextel $312^{\circ}$ ceramic fibers were susceptible to tearing and showed no ability to fold or be formed into simple shapes such as pleats. The Saffil and QPC $300^{\otimes}$ fibers resulted in the most satisfactory papers overall, based on the criteria in Figure 3 and Table III, and were selected as the ceramic fibers to study further.

Table III. Summary of Papers Made with Various Ceramic Fibers

\begin{tabular}{|c|c|c|c|c|}
\hline $\begin{array}{c}\text { Ceramic } \\
\text { Fiber }\end{array}$ & Brittleness & $\begin{array}{c}\text { Ability to } \\
\text { Fold }\end{array}$ & $\begin{array}{c}\text { Ease of } \\
\text { Tearing }\end{array}$ & $\begin{array}{c}\text { Ease of } \\
\text { Handling }\end{array}$ \\
\hline Saffil & not brittle & very good & high & excellent \\
\hline Nextel $312^{\circledR}$ & not brittle & poor & low & very good \\
\hline $\mathrm{QPC} 300^{\circledR}$ & not brittle & very good & high & excellent \\
\hline $\begin{array}{c}\mathrm{Al}_{2} \mathrm{O}_{3}: \mathrm{SiO}_{2} \\
(60 \%: 40 \%)\end{array}$ & not brittle & very good & high & poor \\
\hline $\begin{array}{c}\mathrm{Al}{ }_{2} \mathrm{O}_{3}: \mathrm{SiO}_{2} \\
(87 \%: 13 \%)\end{array}$ & not brittle & very good & high & poor \\
\hline Fiberglass & very brittle & poor & low & moderate \\
\hline $\begin{array}{c}\text { Whatman } \\
\text { filter }\end{array}$ & not brittle & very good & low & excellent \\
\hline
\end{tabular}

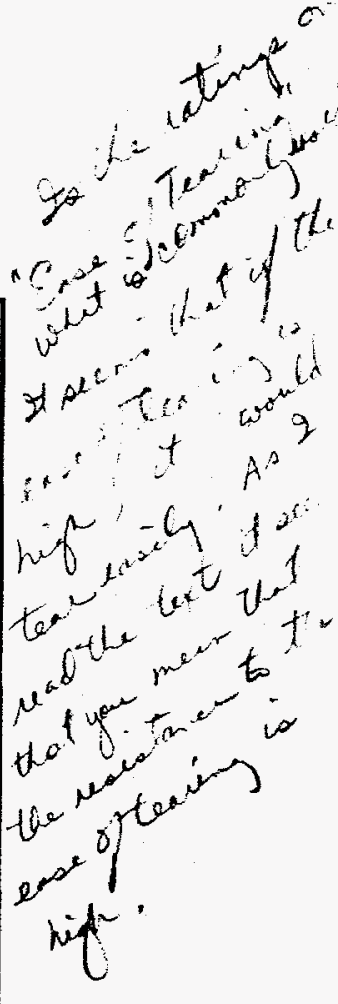

Bond Phase Particle Capture

One method of incorporating the particulate ceramic bond phase into the paper is to add it to the fiber slurry before the paper is formed. When using this method, it is desirable to know the distribution of the particles in the paper. To model the 
distribution of particulate glass bond phase, one gram of silicon carbide particles of known size was used. The black silicon carbide particles were easily seen under an optical microscope, as opposed to the white glass particles. The silicon carbide particles could be counted to determine the number of particles per area of paper as a function of particle size and the specific region of the paper being studied, i.e. the center or the edge. Silicon carbide particles of 14.5,23, and 50 micron diameter were used. Using an optical microscope, the number of particles observed in a known area were counted. A hole punch was used to remove samples from the outer edge and middle of the paper. Observations were made on both the top and bottom surfaces of each sample. Specimens were then peeled apart to make observations on the inside of the paper.

When Saffil ${ }^{\circledR}$ was used as the ceramic fiber the distribution of particles showed some dependence on the particle size. In these instances, the 50 micron silicon carbide particles were more numerous in the middle of the paper than along the edge, while the opposite was true of 14.5 micron particles. The 23 micron particles resulted in the most uniform distribution between the edge and middle of the paper. When QPC 300 fibers were used the particle distribution was much more uniform across the paper, independent of the particle size used. For all samples, it was observed that more particles were captured in the inner layers of the papers than the outer surfaces, independent of the ceramic fiber used.

The average number of particles per area for several papers is shown in Figure 4. Blends of QPC $300{ }^{\circ}$ and QPC $125{ }^{\circledR}$ ( 80\%:20\% and 50\%:50\%) were used to study the effect of fiber length (Table I) in particulate bond phase capture. As seen in Figure 4, the QPC fibers were slightly more efficient at capturing bond phase than the smaller Saffil ${ }^{\circledR}$ fibers. More small particles (14.5 and 23 micron) were captured in papers made of QPC 125 ceramic fiber than QPC $300{ }^{\circ}$. The papers studied to obtain the results in Figure 4 contained fibrillated acrylic binder fiber and Crestbrook pine bulking fiber. As discussed previously, the fibrillation of the acrylic makes this fiber very efficient at capturing particles. To determine the particle capture caused only by the ceramic fibers and remove any effect due to the fibrillated acrylic, the experiment was repeated with papers which did not contain acrylic fiber. These papers retained only two particles $/ \mathrm{mm}^{2}$, regardless of the ceramic fiber used. To determine how much bond phase was present in a paper which was formed with acrylic, and subsequently subjected to binder burnout, the papers used in Figure 4 were heated to $800^{\circ} \mathrm{C}$ and the silicon carbide particles recounted. When compared to the data in Figure 4, no significant change in the number of particles present was noted.

\section{Initial Model of Ceramic Filter Paper}

Preliminary calculations were made to begin development of a model to describe the geometry of the filter papers. Using known quantities such as the dimensions of the papers, the amount and density of ceramic fibers used, and the amount and density of silicon carbide used, several properties of the papers were calculated. While the detailed calculations are not reported here, the results are summarized in 
Table IV. All the values in Table IV were determined based on 23 micron silicon carbide particles as model ceramic bond phase. The observed particle per area values listed in Table IV were acquired from papers containing 23 micron silicon carbide. Good agreement was found for the calculated and observed numbers of particles permm². what constitutes"goodagreement?"

Table IV. Properties of Paper

\begin{tabular}{|c|c|c|c|c|c|}
\hline $\begin{array}{l}\text { Ceramic } \\
\text { Fiber }\end{array}$ & $\begin{array}{l}\% \\
\text { Porosity }\end{array}$ & $\begin{array}{l}\text { Length } \\
\text { Ceramic } \\
\text { Fiber@ }\end{array}$ & $\begin{array}{l}\text { Particle/ } \\
\text { Length }\end{array}$ & $\begin{array}{l}\text { Particle/ } \\
\text { Area }\end{array}$ & $\begin{array}{l}\text { Observed } \\
\text { Particle/Area }\end{array}$ \\
\hline Saffil® & 94.8 & $84.8 \mathrm{~km}$ & $0.58 / \mathrm{mm}$ & $3.2 / \mathrm{mm}^{2}$ & $8 / \mathrm{mm}^{2}$ \\
\hline $\begin{array}{l}\text { QPC } \\
300^{\circ}\end{array}$ & 93.3 & $48.7 \mathrm{~km}$ & $1 / \mathrm{mm}$ & $9.5 / \mathrm{mm}^{2}$ & $11 / \mathrm{mm}^{2}$ \\
\hline $\begin{array}{l}\mathrm{QPC} \\
125^{\circ}\end{array}$ & 93.3 & $20 \mathrm{~km}$ & $2.45 / \mathrm{mm}$ & $14.9 / \mathrm{mm}^{2}$ & $38 / \mathrm{mm}^{2}$ \\
\hline
\end{tabular}

Samples from fired papers containing one of four ceramic bond phases were tested using a biaxial load test. Glass bond phases 7052, 7056, and 9013 were added to slurries of Saffil ${ }^{\otimes}$ paper in 5 and 10 gram quantities. The colloidal silica bond phase was incorporated into papers by dipping Saffil papers in $5 \%, 10 \%$, or $30 \%$ aqueous colloidal silica solutions prior to firing. These papers contained approximately $0.4 \mathrm{~g}, 0.7 \mathrm{~g}$, and $2.2 \mathrm{~g}$ of silica, respectively. The relative breaking loads for all samples are presented in Figure 5. Papers containing 5 grams of 7052 glass bond phase were half as strong as papers containing 10 grams of 7052 . The relative strengths of papers containing colloidal silica increased in the ratio 1:3:6.5 as the amount of silica in the paper increased in the ratio 1:2:6. These examples indicate that increasing the amount of bond phase results in an increase in the number of bonds between fibers in the paper, thereby increasing the strength of the paper proportionally. The strength of papers made with 7056 and 9013 glass bond phases did not increase with the amount of bond phase added. This could be due to insufficient wetting of the bond phase on the fibers, possibly caused by surface chemistry problems or a firing temperature which was not high enough. The displacement observed during loading was approximately $50 \%$ greater for the papers made with glass bond phase than for those made with colloidal silica. Papers made with glass or colloidal silica bond phase showed strain-tolerant behavior during testing, and exhibited graceful rather than catastrophic failure. A plot representative of the failure behavior of all the papers is presented in Figure 6. 


\section{SUMMARY}

Filter papers were made using Saffil ${ }^{\circledast}$ and fused quartz ceramic fibers, acrylic binder fifurs, bulking fiber, and ceramic bond phase. The fibers used were selected by tensile testing of papers made with several different ceramic and organic fibers. Glass and colloidal silica were used as the ceramic bond phase and were incorporated into the papers by addition to the fiber slurry or by dip coating prior to firing. Firing temperatures were determined experimentally. Silicon carbide particles of known size were used to model the distribution of particulate bond phase in the papers. The number of particles in a known area were counted under an optical microscope. More particles were captured in the inner layers of paper than the top or bottom surfaces. The particle distribution in the edge and center of the papers showed some dependence on particle size. As the ceramic fiber increased in length and diameter the calculated distance between particles decreased. The calculated number of particles per $\mathrm{mm}^{2}$ showed good agreement with the observed number of particles per $\mathrm{mm}^{2}$. Fired papers were subjected to biaxial load tests. The strength of papers made with 7052 glass and colloidal silica showed a dependence on the amount of bond phase included in the paper. All samples exhibited strain-tolerant behavior.

† Polyethylene, Dupont Co., Wilmington, DE

$\S$ Polyester, Schuller International, Denver, CO

$\ddagger$ Polypropylene, Hercules, Passaic, NJ

a Cellulose Acetate, Hoescht-Celanese, Somerville, NJ

\# Cellulose (high alpha), Rayonier, Stamford, CT

If Fibrillated Acrylic (114-3), Cytec Industries Inc., Stamford, CT

* Kimwipe, Kimberly-Clark Corp., Roswell, GA

+ Crestbrook pine pulp, Buckeye Cellulose Corp., Memphis, TN

$\checkmark$ Colloidal Silica, Matheson, Coleman, and Bell, Cincinnati, $\mathrm{OH}$

¥ Sealing Glasses, Corning, Corning, NY

** Williams Standard Handsheet Mold, Testing Machines Inc., Amityville, NY

\section{REFERENCES}

1. C. N. Davies, Air Filtration, Academic Press, London, 1973,

2. M. Tomita, S. Tadagi, "Method for Producing a Ceramic Filter for Cleaning Exhaust Gases from a Diesel Engine", U. S. Pat. 4540535 (1985).

3. J. Abthoff, H. D. Schuster, G. Loose, B. Jokl, "Exhaust Gas Filter for Diesel Engine", U. S. Pat. 4704863 (1987).

4. “Exhaust Gas Filter", U. S. Pat. 1498130 (1978).

5. H. P. Schiffer, S. Laux, U. Renz, "High Temperature Gas Filtration", GS6489, Research Project 1336-07, Electric Power Research Institute, Palo-Alto, CA, (1992). 


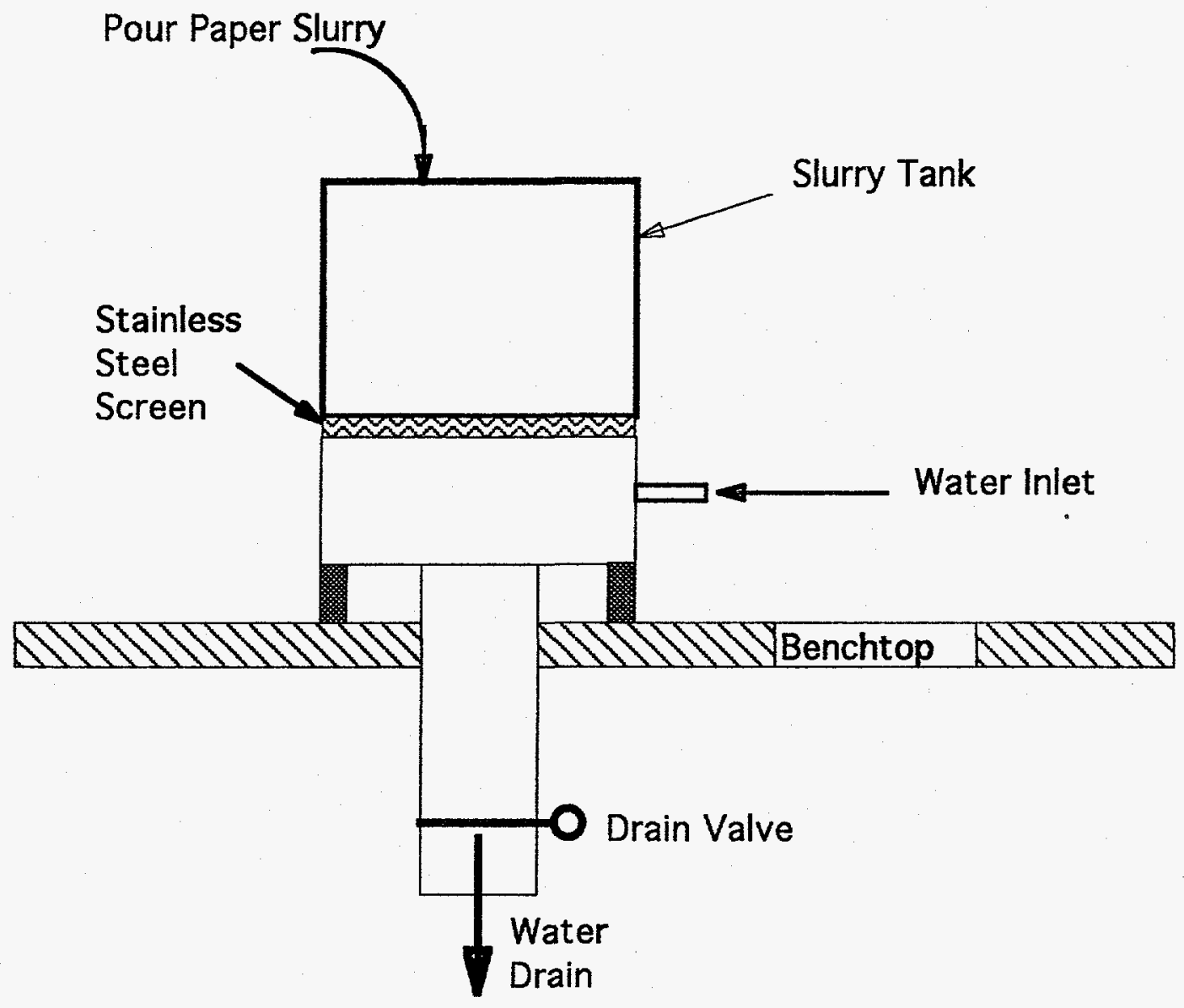

Figure 1: Williams Standard Handsheet Mold 


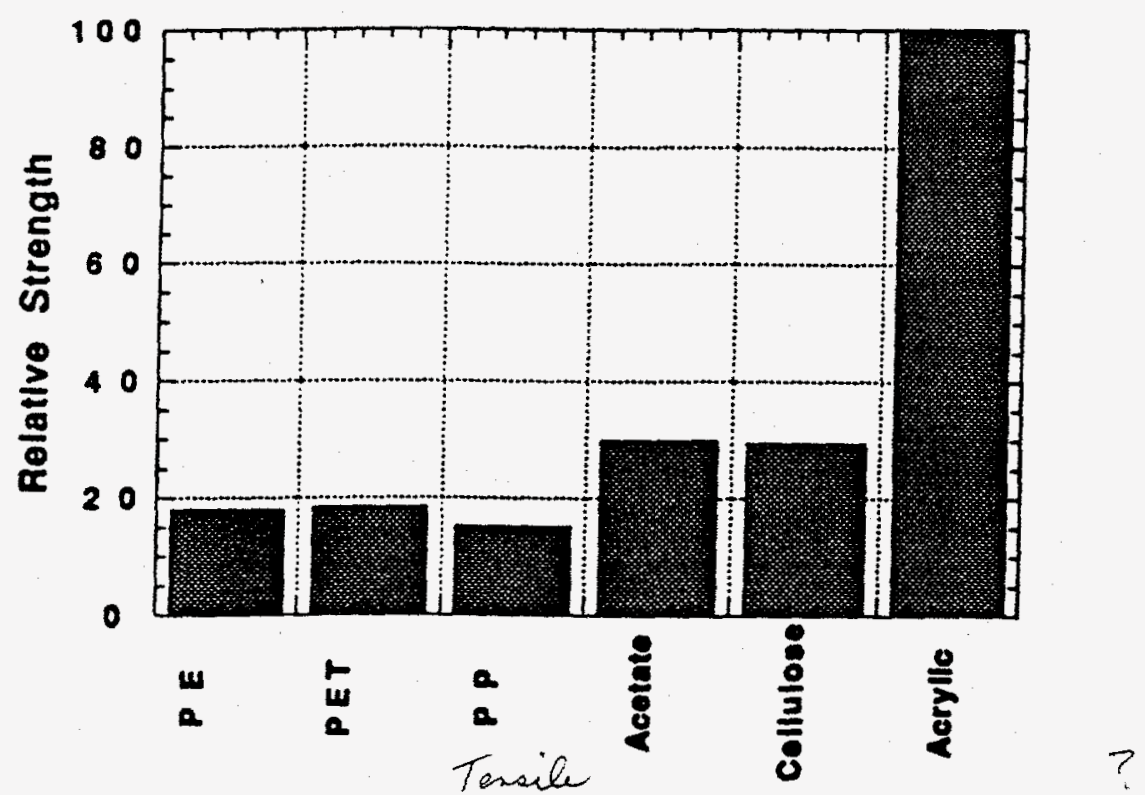

Figure 2: Relative Strengths of Binder Fibers

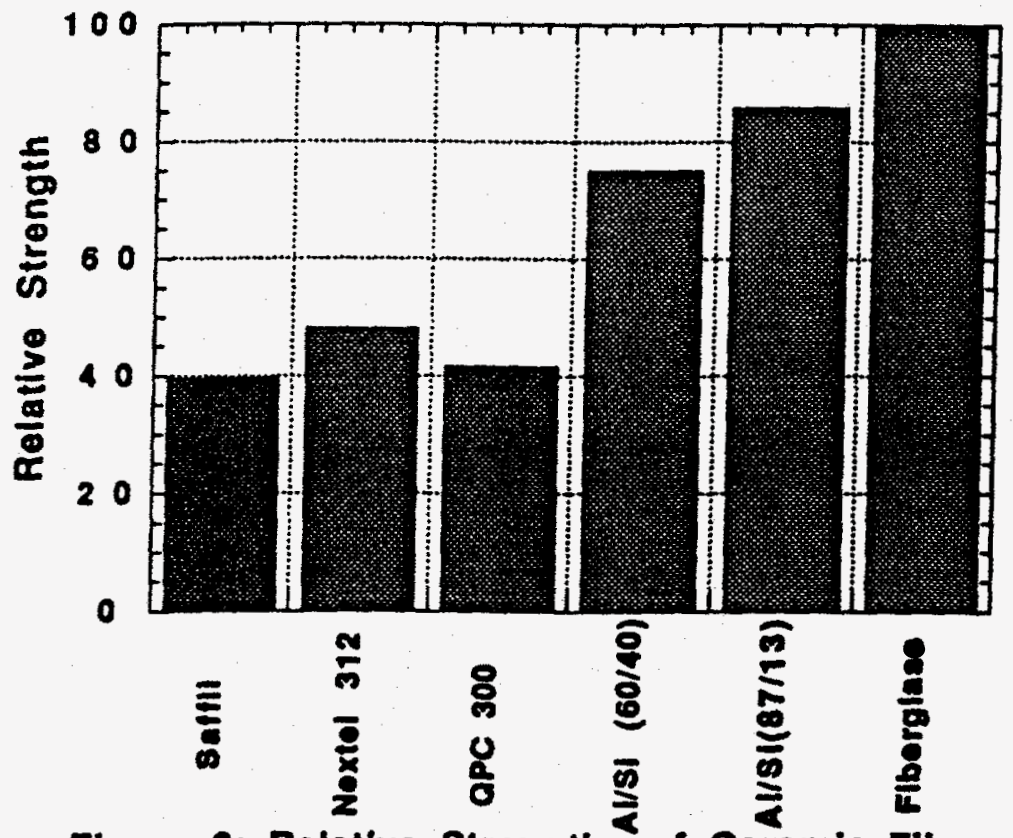

Figure 3: Relative Strengths of Ceramic Fibers in 


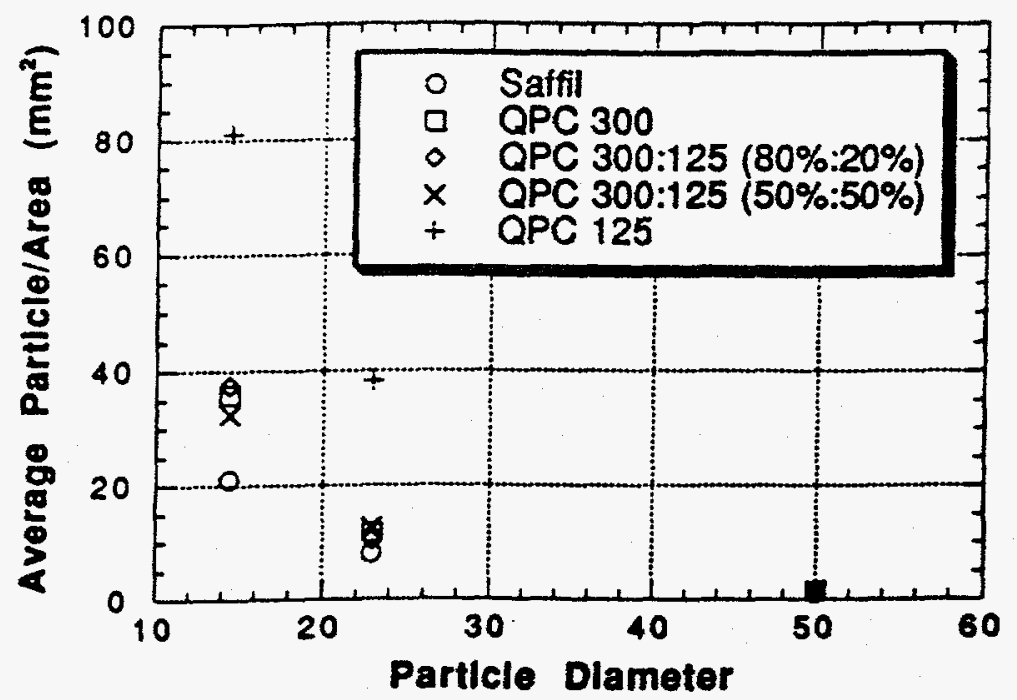

Figure 4: Particulate Bond Phase/Area

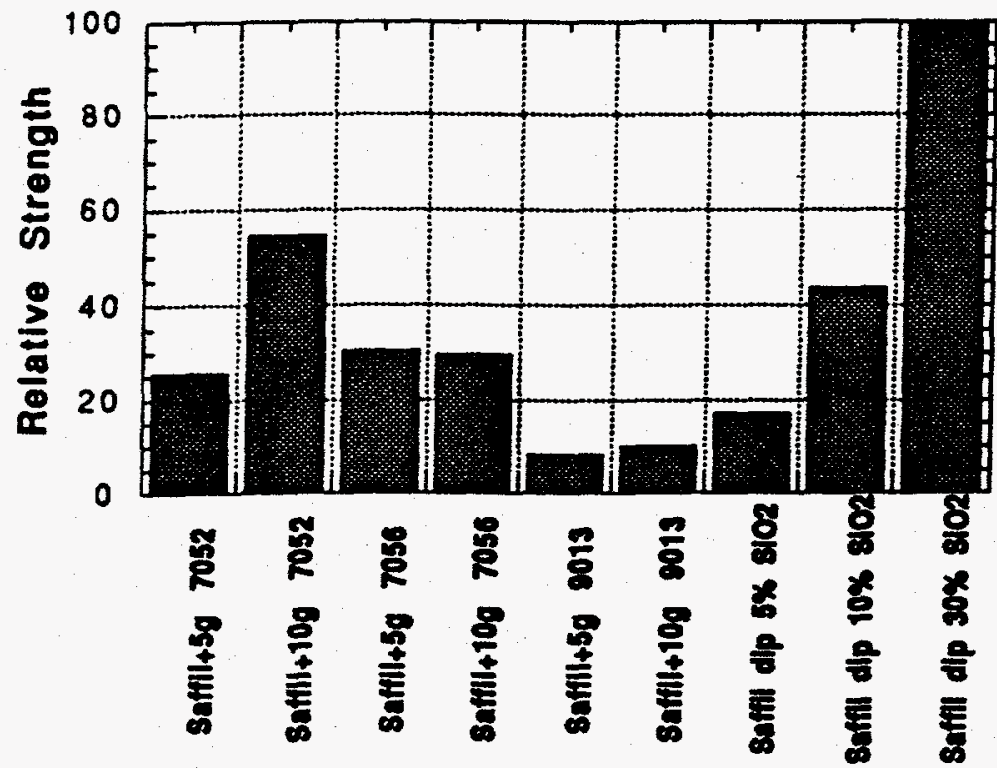

Figure 5: Relative Compression Strength of Fired Papers 


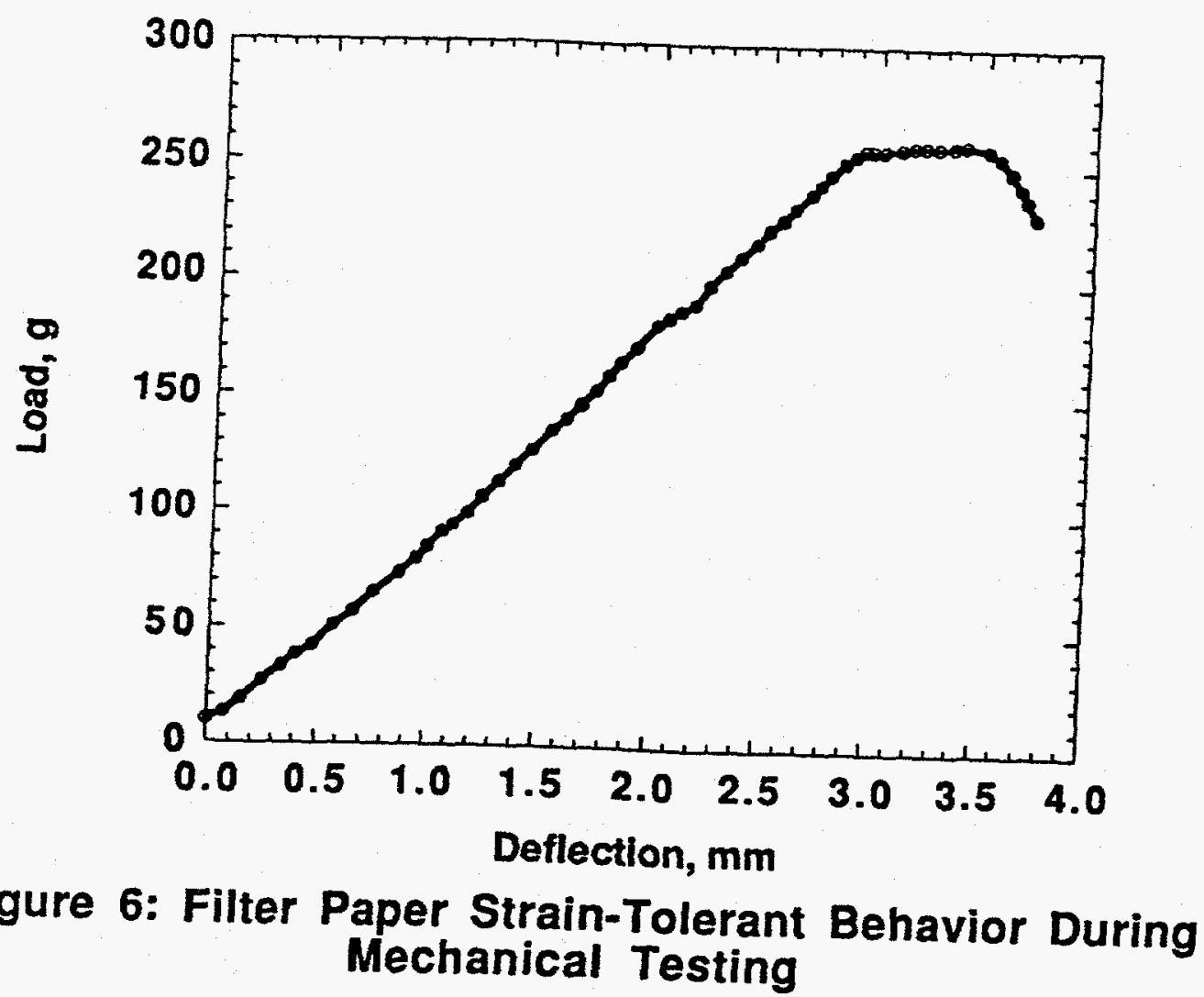

DISCLAIMER

This report was prepared as an account of work sponsored by an agency of the United States Government. Neither the United States Government nor any agency thereof, nor any of their employees, makes any warranty, express or implied, or assumes any legal liability or responsibility for the accuracy, completeness, or usefulness of any information, apparatus, product, or process disclosed, or represents that its use would not infringe privately owned rights. Reference herein to any specific commercial product, process, or service by trade name, trademark, manufacturer, or otherwise does not necessarily constitute or imply its endorsement, recommendation, or favoring by the United States Government or any agency thereof. The views and opinions of authors expressed herein do not necessarily state or reflect those of the United States Government or any agency thereof. 